\title{
ANALISIS TINDAK TUTUR HUMAS PT. KERETA API INDONESIA (PERSERO) DAERAH OPERASI 4 SEMARANG DALAM MENSOSIALISASIKAN SOP TENTANG REKOMENDASI IBU HAMIL (STUDI KASUS IBU MELAHIRKAN DI KA KERTAJAYA LEBARAN)
}

\author{
Putri Tiara Loka, Devi Purnamasari \\ Universitas Dian Nuswantoro Semarang \\ p.tiaraloka@gmail.com,devi.purnamasari9@dsn.dinus.ac.id
}

\begin{abstract}
Asbtrak
PT. Kereta Api Indonesia (Persero) memiliki berbagai macam pedoman yang digunakan untuk mengimplementasikan 4 pilar perusahaan. Khususnya adalah Keselamatan, Ketepatan Waktu, Keamanan dan Kenyamanan. Salah satu peraturan yang di publikasikan adalah peraturan khusus untuk ibu hamil sebagai pedoman keselamatan bagi penumpang. Umumnya, penumpang ibu hamil yang menempuh perjalanan jauh dengan menggunakan kereta api. Tujuan dari penelitian ini adalah untuk mengetahui bagaimana proses sosialisasi SOP No. 1/KS.102/II/ $\mathrm{MMH} / 9001 / 2017$ yang dilakukan Humas kepada ibu hamil tentang peraturan perusahaan dengan menggunakan teori tindak tutur. Penelitian ini menggunakan metode wawancara, observasi dan dokumentasi. Teori yang digunakan dalam penelitian ini menggunakan teori tindak tutur milik John Searle. Hasil penelitian menunjukan bahwa Humas dapat menyampaikan tuturan dengan jelas kepada penumpang. Tindak tutur lokusi menyampaikan pernyataan isi tertentu untuk mendapatkan hubungan kerja sama yang baik dengan penumpang. Tindak tutur ilokusi disampaikan melalui berbagai media, antara lain media massa, media audio visual berupa KA TV, kegiatan Humas seperti himbauan dari announcer, talkshow dan jumpa pers serta iklan media massa berupa roll banner, dan spanduk di stasiun. Tindak tutur perlokusi memberikan hasil bahwa dominasi penumpang paham dan melaksanakan sesuai dengan peraturan yang telah dibuat oleh perusahaan.
\end{abstract}

\section{Kata Kunci : PT. KAI (Persero), Tindak Tutur, Sosialisasi}

\begin{abstract}
PT. Kereta Api Indonesia (Persero) has a variety of guidelines that are used to implement the 4 pillars of the company. Especially is Safety, Timeliness, Security and Comfort. One of the regulations published is a special regulation for pregnant women as a safety guideline for passengers. Generally, passengers of pregnant women who travel long distances by train. The purpose of this study was to find out how the process of socializing SOP No. 1 / KS.102 / II / $\mathrm{MMH} / 9001 / 2017$ conducted by $P R$ to pregnant women about company regulations using speech act theory. This research uses interview, observation and documentation methods. The theory used in this study uses John Searle's theory of speech acts. The results of the study show that Public Relations can convey speech clearly to passengers. Location speech acts convey certain content statements to get a good working relationship with passengers. Illocutionary speeches were delivered through various media, including mass media, audio-visual media in the form of TV trains, public relations activities such as appeals from announcers, talk shows and press conferences and mass media advertisements in the form of roll banners, and banners at stations. Perlokusi speeches result that the dominance of passengers understands and executes in accordance with the regulations made by the company.
\end{abstract}

Keywords: PT. KAI (Persero), Speech Acts, Socialization 


\section{Pendahuluan}

PT. Kereta Api Indonesia (Persero) merupakan salah satu transportasi umum yang melayani berbagai macam rute keberangkatan di Indonesia. Semakin berkembangnya rute keberangkatan disebabkan oleh survey minat dan masukan yang disampaikan penumpang, sehingga membuat perusahaan kereta api berusaha untuk memenuhi kebutuhan penggemar moda kereta api melalui antusias keinginan penumpang untuk menambahkan rute perjalanan baru. Untuk mewujudkan visi dan misi perusahaan, sebuah instansi didukung dengan adanya peraturan yang mengikat dan harus selalu dipatuhi oleh semua elemen baik internal maupun eksternal, sehingga visi misi yang diharapkan dapat sejalan dengan keinginan perusahaan.

PT. Kereta Api Indonesia (Persero) membuat sebuah peraturan mengenai rekomendasi ibu hamil dengan tujuan untuk keamanan dan kenyamanan semua pengguna transportasi kereta api. Peraturan yang bersifat umum, diharapkan dapat ditaati oleh penumpang khususnya ibu bagi ibu hamil yang memilih untuk menggunakan kereta api sebagai transportasi jarak jauh, sehingga dapat meminimalisir keadaan genting yang tidak sesuai dengan keinginan stakeholders dari internal maupun eksternal yang dapat mengganggu kenyamanan dan keamanan saat melakukan perjalanan menggunakan kereta api.

Standar Operasional Prosedur (SOP) adalah sekumpulan peraturan yang digunakan sebagai panduan kegiatan sebuah organisasi atau perusahaan agar kegiatan tersebut dapat berjalan dengan lancar (Sailendra, 2015:11). SOP adalah dokumen yang didalamnya berisi tatanan peraturan yang tertulis sebagai panduan dalam proses penyelenggaraan kegiatan administrasi yang isinya berupa cara, waktu, tempat dan tokoh yang memiliki peran dalam kegiatan tersebut (Insani, 2010:1). Dari pengertian tersebut dapat disimpulkan bahwa SOP adalah alat yang digunakan sebagai aturan atau patokan untuk melakukan suatu kegiatan, yang dilengkapi dengan berbagai pedoman yang beresiko, sehingga dapat dilakukan revisi sesuai dengan situasi dan kondisi dilapangan.

Dukungan yang dilakukan oleh perusahaan salah satunya berupa sosialisasi mengenai peraturan atau SOP perusahaan yang menyangkut keselamatan penumpang. PT. Kereta Api Indonesia (Persero) memberikan tanggung jawab sepenuhnya pada divisi Humas yang memiliki peran untuk terjun langsung ke masyarakat. Sosialisasi tersebut sangat penting dilakukan dengan memberikan pejelasan dengan rinci dan mudah dipahami, sehingga masyarakat juga memiliki kesadaran yang sama dengan yang dimiliki perusahaan terkait dengan keselamatan selama di perjalanan. Peran Humas sebagai komunikator juga memiliki peran penting untuk mensukseskan sosialisasi yang diselenggarakan untuk kepentingan perjalanan kereta api. PT. Kereta Api Indonesia (Persero) dituntut untuk selalu memperhatikan segala peraturan yang menyangkut dengan keselamatan.

Sesuai dengan 4 pilar utama perusahaan, yakni Keselamatan, Ketepatan waktu, Kenyamanan dan Keamanan, maka untuk mewujudkan prinsip tersebut, PT. KAI selalu berusaha 
untuk membuat suatu regulasi yang memberikan pedoman terbaik ketika melaksanakan suatu kegiatan yang menyangkut 4 pilar tersebut. Melalui unit Humas di PT. Kereta Api Indonesia (Persero), Humas harus mampu mensosialisasikan peraturan dan mengakomodir masyarakat untuk perduli dengan kenyamanan dan keselamatan penumpang lain. Cara sosialisasi yang dilakukan memiliki perbedaan pada setiap tingkatan strata kehidupan, sesuai dengan tingkat pemahaman masyakat yang berbeda. Berhasil atau tidaknya suatu kegiatan sosialisasi, bergantung dengan bagaimana cara Humas mendekatkan diri dengan pihak eksternal perusahaan, sehingga dapat memberikan suatu pemahaman yang sejajar dengan keinginan perusahaan.

Salah satu peraturan yang disosialisasikan pada masyarakat terkait dengan keselamatan perjalanan KA adalah peraturan mengenai Ibu Hamil yakni peraturan No. 1/KS.102/II/ $\mathrm{MMH} / 9001 / 2017$. Untuk mendapatkan dukungan dari masyarakat, pihak Humas berperan melakukan pendekatan persuasif dengan cara melakukan penyuluhan secara tatap muka bertahap. Selain itu, Humas memastikan bahwa pesan yang dipublikasikan dapat diterima dan tersampaikan dengan baik kepada masyarakat. Selain penyuluhan, Humas juga memberikan informasi melalui iklan media cetak, elektronik, internet, spanduk dan backdrop untuk mengajak masyarakat ikut mensukseskan program yang dilaksanakan. Berhasil atau tidaknya suatu sosialisasi tergantung dari cara komunikator untuk mengkomunikasikan kepada masyarakat dengan efektif, sehingga akan terjalin hubungan yang intens dan saling mendukung antara pihak satu dan yang lainnya

Manager Humasda Daop 1 mengatakan bahwa regulasi dibuat untuk memberikan rasa aman dan nyaman kepada penumpang yang dalam kondisi hamil. Rekomendasi yang diberikan jika ibu hamil tidak membawa surat dokter sesuai aturan yang sudah ditetapkan adalah bersedia untuk memeriksakan kehamilannya di pos kesehatan yang tersedia di stasiun keberangkatan penumpang hamil tersebut (https://news.detik.com/) diakses tanggal 04/12 09.29 WIB).

Jika penumpang ibu hamil yang melaksanakan perjalanan jauh menggunakan kereta api memiliki usia kandungan 0-13 minggu atau 29-36 minggu, maka wajib untuk membawa surat keterangan dokter yang menyatakan bahwa kondisi kandungan sedang dalam keadaan baik. Penumpang ibu hamil juga harus ditemani 1 pempang dewasa ketika menjalani perjalanan jauh menggunakan kereta api (https://lifestyle.kompas.com/), diakses tanggal 04/12 09.42 WIB).

Sesuai dengan peraturan No. 1/KS.102/II/MMH/9001/2017 mengatur bahwa ketentuan ibu hamil yang diperbolehkan untuk menaiki kereta api adalah dengan usia kandungan 14 28 minggu. Pada salah satu postingan Instragram tersebut, PT. KAI memberikan himbauan sekaligus sosialisasi mengenai perjalanan kereta api bagi ibu hamil, bahwa ibu hamil dengan usia kehamilan 14-28 minggu diperbolehkan untuk menaiki kereta api jarak jauh. Apabila ibu 
hamil memaksakan untuk menaiki kereta api diluar rentang tersebut, diharuskan membawa surat keterangan dokter kandungan atau bidan yang menyatakan bahwa kandungan dalam keadaan sehat dan tidak ada kelainan. Ibu hamil juga harus didampingi oleh satu orang dewasa jika ingin melakukan perjalanan jauh menggunakan kereta api. Namun pada tanggal 17 Juni 2018, terdapat pemberitaan bahwa ada penumpang KA Kertajaya Lebaran dengan relasi Jakarta Pasar Senen - Surabaya Pasar Turi yang melahirkan.

Pemudik asal Madura bernama Nuzulul Hikmah (23) warga Sampang Madura, Jawa Timur melahirkan diatas kereta api saat melakukan perjalanan jauh dari Stasiun Pasar Senen menuju ke Stasiun Pasar Turi. Menurut informasi yang didapat dari Manager Humasda Daop 4, Ibu hamil sudah merasakan kontraksi diatas kereta, saat sampai di Stasiun Kaliwungu, suami ibu tersebut yang bernama Jamil (32) melaporkan keluhan istrinya kepada kondektur kereta yang ditumpangi (https://www.cnnindonesia.com), diakses tanggal 04/12, 09.50 WIB).

Situasi gerbong kereta saat itu sempat heboh karena seluruh penumpang mengetahui bahwa salah seorang penumpang merasakan kontraksi saat masih dalam perjalanan menuju ke daerah Kaliwungu, sehingga kondektur menanyakan kepada penumpang lain adakah yang memiliki keahlian atau profesi sebagai bidan atau tenaga kesehatan guna membantu jalannya persalinan di atas kereta api Kertajaya Lebaran saat itu. Akhirnya salah seorang penumpang yang memiliki profesi ditenaga kesehatan bersedia membantu untuk proses persalinan di atas kereta api (https://www.jawapos.com/), diakses tanggal 04/12, 09.59 WIB).

Sosialisasi menjadi salah satu kegiatan yang ikut menggunakan ruang kebebasan tersebut dengan tujuan untuk menginformasikan suatu kegiatan yang dilakukan oleh individu maupun perusahaan. Dengan adanya sosialisasi, informasi yang di sampaikan dapat menyebar dengan baik ke seluruh lapisan masyarakat yang terikat kepentingan dengan suatu organisasi tersebut. Salah satu bentuk komunikasi dalam sosialisasi adalah menggunakan kata - kata.

Tindak tutur merupakan analisis yang mempelajari bahasa antara konteks tuturan dengan maksud dari tuturan yang disampaikan. Menurut Ismail, 2013 : 23, menjelaskan bahwa analisis ini mempelajari tentang ujaran, menanyakan apa pemahaman seseorang terkait dengan tindak tutur, dan mengaitkan makna tuturan yang disampaikan. Tindak tutur juga bisa dilakukan dengan menggunakan media iklan berupa spanduk, yang berisikan pernyataan, memeritahukan, perintah, menawarkan suatu barang, mengingatkan akan sesuatu hal, mengajak kearah yang lebih baik, ancaman bagi orang yang mencuri, larangan, dan ucapan selamat atas suatu pencapauan hasil (Arum Puji, 2014:2)

Keterlibatan Humas dalam mensosialisasikan peraturan No. 1/KS.102/II/ $\mathrm{MMH} / 9001 / 2017$ mengenai rekomendasi ibu hamil untuk perjalanan jarak jauh ini membuat peneliti tertarik untuk meneliti lebih mendalam. Melalui penelitian ini, peneliti bermaksud untuk mengetahui bagaimana proses sosialisasi yang dilakukan terkait peraturan No. 1/ KS.102/II/MMH/9001/2017 kepada stakeholder eksternal yakni penumpang dan mengetahui 
evaluasi yang dilakukan setelah adanya kejadian ibu melahirkan diatas kereta api pada Juni 2018, yang tidak sesuai dengan isi dari peraturan yang sudah ditetapkan pada Maret 2017 oleh Direktur Utama dan jajaran Direksi perusahaan PT. Kereta Api Indonesia (Persero).

\section{Tinjauan Pustaka}

\subsection{Teori Tindak Tutur}

\section{a. Pengertian Teori Tindak Tutur}

"Speech act theory, attributed to John Searle, is interested in how we accomplish things with words. Speech act theory identifies what it takes to make a successful statement-to have an intention understood" (Little Jhon, 2017:121)

Jhon Searle mengungkapkan, teori tindak tutur dapat digunakan sebagai alat ukur untuk memahami pada bagaimana kita menemukan hal-hal dengan kata-kata. Teori tindak tutur mengidentifikasi apa yang diperlukan untuk membuat pernyataan berhasil dipahami oleh komunikan. Teori ini ingin memberikan persepsi bahwa kata - kata juga memiliki arti yang mendalam. Dengan pemilihan kata yang baik, diharapkan pendengar bisa memahami arti dari kata yang keluar lewat mulut pembicara, sehingga memiliki sebuah arti yang sama dengan keinginan komunikator.

Austin (dalam Rusminto, 2010:22) mengatakan bahwa bertutur tidak hanya sebatas pada pengucapan kalimat, akan tetapi juga melakukan sesuatu atas dasar kalimat yang disampaikan sebelumnya. Pendapat Austin didukung oleh Searle (dalam Rusminto, 2010:22), yang mengatakan bahwa bagian paling kecil dari komunikasi bukanlah kalimat, akan tetapi sebuah tindakan berupa tindakan, pernyataan, permintaan atau perintah.

\section{b. Klasifikasi Teori Tindak Tutur}

Model komunikasi ini dapat diartikan bahwa dalam Rusminto, (2010:22-23) membagi teori tindak tutur menjadi tiga bagian, yakni lokusi, ilokusi, dan perlokusi.

1. Tindak tutur lokusi adalah tindakan mengucapkan suatu pernyataan yang lebih menitik beratkan pada isi pernyataan atau tentang sesuatu. Austin dalam Nadar (2009: 11-12) menyatakan ada tiga syarat yang harus dipenuhi agar suatu tindakan dapat berlaku disebut dengan felicity conditions, yaitu:

(1) Pelaku dan situasi harus sesuai, misalnya tuturan yang sering disampaikan kepada peserta lomba, ("Saya nyatakan kamu lolos ke babak berikutnya"). Tuturan tersebut hanya dapat dipenuhi bila yang mengucapkan adalah seseorang yang memang berwenang untuk mengucapkan tuturan tersebut, misalnya MC atau juri lomba. 
(2) Tindakan harus dilaksanakan dengan lengkap dan benar oleh semua pelaku, misalnya, seorang kakak yang mengatakan ("Kamu benar-benar salah") kepada adiknya dan tidak bisa menunjukkan kesalahannya ataupun hal apa yang membuatnya dianggap salah merupakan tuturan yang tidak valid. Jadi disini dijelaskan bahwa dalam bertutur harus ada bukti yang valid sehingga tidak terkesan menuduh.

(3) Pelaku harus mempunyai maksud yang sesuai, misalnya tuturan ("Saya akan menemui kamu besok Pukul 13.00 WIB"). Sedangkan sebetulnya pukul 13.00 WIB penutur tersebut telah mengadakan janji lain dengan pihak lain, maka tuturan tersebut tidak sesuai.

2. Tindak tutur ilokusi adalah proses mengidentifikasikan isi dari pesan atau pernyataan berupa suatu tindakan sesuai dengan isi pesan yang disampaikan oleh seseorang. Tindak tutur ilokusi merupakan komponen terpenting dalam memahami tindak tutur. Tindak tutur ilokusi adalah tindak tutur yang mempengaruhi seseorang untuk melakukan tindakan tertentu dalam hubungannya dengan mengatakan sesuatu (an act of doing somethings in saying somethings) (Austin dalam Rusminto, 2012: 77).

Tindak tutur ilokusi adalah tindak tutur yang biasanya diidentifikasikan dengan kalimat meminta tindakan yang ekspresif (Chaer, 2010: 53). Misalnya, "Ayah menyuruh saya untuk segera mandi". Jika tindak tutur lokusi berkaitan dengan makna, maka tindak ilokusi berkaitan dengan maksud dalam sebuah rangkaian kata. Dalam kalimat di atas selain memiliki makna juga menyampaikan maksud, yaitu menyuruh untuk segera mandi. Dalam mengidentifikasi tindak ilokusi maka harus diperhatikan penutur dan mitra tuturnya, kapan dan dimana tuturan terjadi, serta saluran apa yang dipergunakan.

Leech (dalam Rusminto, 2010: 23) membagikan berdasarkan hubungan fungsi-fungsi tindak ilokusi dengan tujuan-tujuan sosial berupa pemeliharaan perilaku yang sopan dan terhormat menjadi empat jenis, yaitu sebagai berikut :

1) Kompetitif, seperti memerintah, meminta, menuntut, mengemis.

2) Menyenangkan, seperti menawarkan, mengajak, mengundang, menyapa, mengucapkan terima kasih, mengucapkan selamat.

3) Bekerja sama, seperti menyatakan, melapor, mengumumkan, mengajarkan.

4) Bertentangan, seperti mengancam, menuduh, menyumpahi, memarahi.

Sementara itu, Pateda (dalam Rusminto, 2009: 73) secara lebih sederhana mengklasifikasikan tuturan atas lima klasifikasi, yaitu sebagai berikut :

1) Tuturan yang berisi pernyataan.

2) Tuturan yang berisi suruhan atau penolakan. 
3) Tuturan yang berisi permintaan atau penolakan.

4) Tuturan yang berisi pertanyaan atau jawaban.

5) Tuturan yang berisi nasihat.

3. Tindak tutur perlokusi adalah efek yang ditimbulkan sesaat setelah memahami isi dari sebuah pernyataan. Suatu pernyataan dinyatakan berhasil apabila isi pernyataan tersebut dilakukan sesuai dengan keinginan yang diharapkan oleh komunikator. Menurut Levinson dalam Rusminto (2012: 78) menyatakan bahwa tindak tutur perlokusi lebih menitikberatkan pada efek yang timbul ketika seseorang memahami definisi dan inti dari pernyataan yang telah disampaikan, karena sebuah efek pernyataan tersebut dapat dikatakan berhasil ketika seorang komunikan melakukan suatu efek berupa tindakan yang berkaitan dengan pernyataan yang disampaikan oleh komunikator.

\subsection{Kerangka Pemikiran}

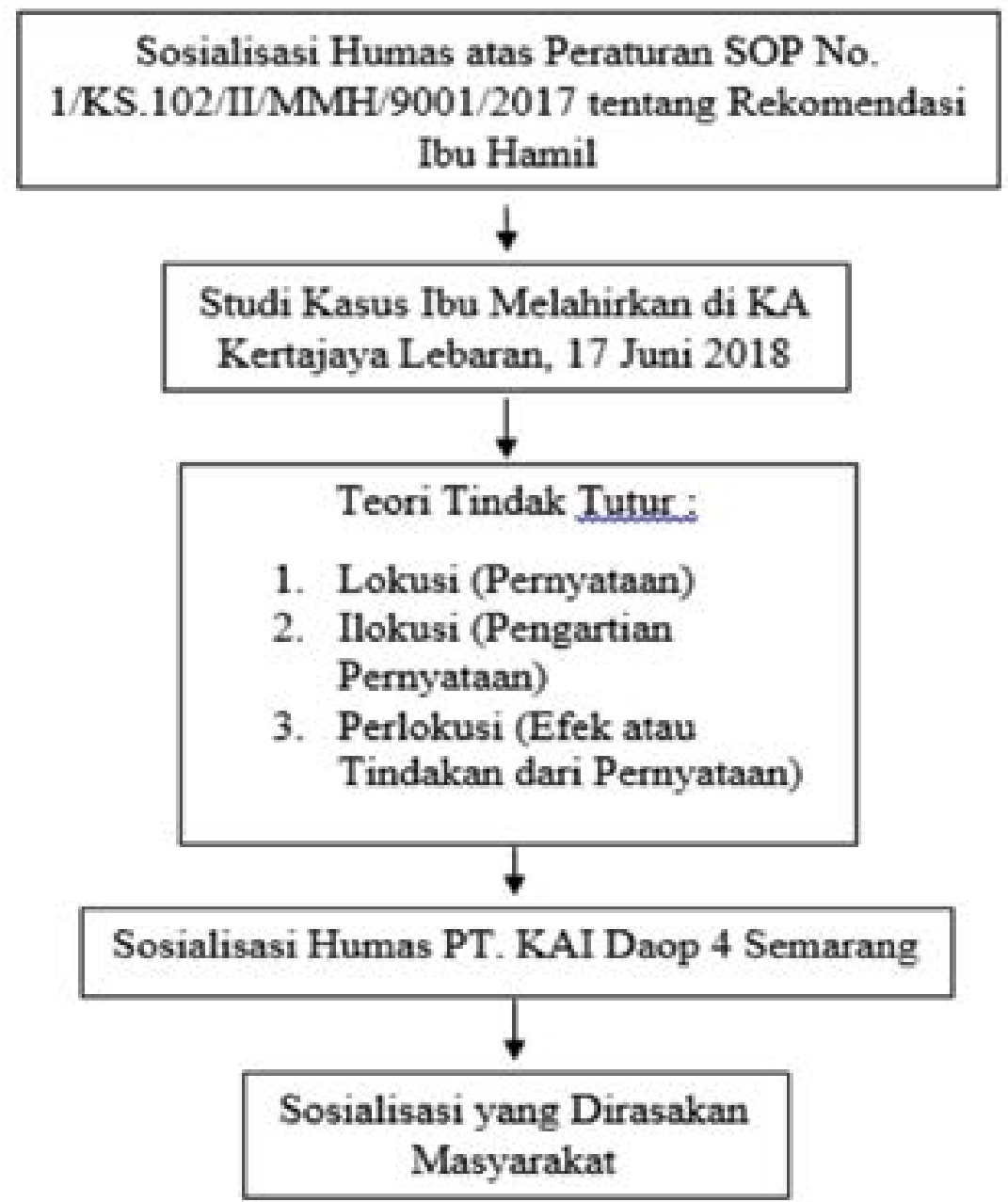




\section{Metode Penelitian}

Penelitian ini merupakan jenis penelitian kualitatif dengan pengertian menurut Bogdan dan Taylor (Moleong, 2007: 4) mendefinisikan metodologi kualitatif sebagai penelitian yang menghasilkan data deskriptif berupa serangkaian kalimat tertulis atau lisan dari narasumber. Pendekatan ini diarahkan pada latar dari individu tersebut secara holistik (utuh). Jadi dalam hal ini narasumber dipandang sebagai suatu keutuhan dan tidak boleh mengucilkan individu lain. Menurut Nana Syaodih Sukmadinata (2005: 60) mengungkapkan bahwa penelitian kualitatif digunakan untuk mendeskripsikan dan menganalisis sebuah fenomena, peristiwa dan kejadian yang dialami seorang individu maupun kelompok. Penelitian ini menggunakan metode studi kasus, yakni penelitian berfokus pada satu kasus untuk diamati dan dianalisis secara cermat sampai tuntas. Analisis dilakukan secara tajam terhadap berbagai macam faktor yang terkait dengan kasus tersebut sehingga akhirnya aja memperoleh kesimpulan yang akurat (Sutedi, 2009:61). Penelitian ini terpusat pada satu objek tertentu dan dipelajari sebagai sebuah studi kasus, dengan mengumpulkan data dari berbagai sumber. (Nawawi, 2003).

Salah satu syarat dalam penelitian studi kasus adalah pada kasus tersebut harus memiliki keunikan tersendiri dibandingkan dengan penelitian yang lain. Keunikan yang ditemui pada kasus dari penelitian ini yaitu peristiwa ibu melahirkan di atas kereta api yang baru pertama kali terjadi di sejarah perkeretaapian Indonesia. Pernyataan ini didukung dengan salah satu data berupa berita melalui media yang dimuat oleh ANTARANEWS.COM pada tanggal 17 Juni 2018 dengan judul "Seorang pemudik melahirkan di dalam kereta api".

Menurut Lincoln dan Guba dalam Dedy Mulyana (2004: 201) dengan menggunakan studi kasus sebagai suatu metode penelitian kualitatif, dapat memiliki beberapa keuntungan, pertama, studi kasus memberikan informasi dari subjek yang diteliti, kedua, studi kasus menampilkan uraian secara keseluruhan dengan mirip dan sesuai dengan yang dialami oleh pembaca, ketiga, studi kasus merupakan cara untuk mendekatkan diri antara peneliti dengan narasumber, yang terakhir, studi kasus dapat memberikan uraian mendalam yang diperlukan bagi peneliti.

\section{Hasil Penelitian}

Teori tindak tutur merupakan sebuah teori yang digunakan sebagai alat ukur untuk memahami sebuah rangkaian kata yang diucapkan atau disampaikan seseorang kepada orang lain dengan mengandung maksud dan tujuan tertentu. Penangkapan kalimat atau kata - kata tersebut dapat memiliki arti yang berbeda, sehingga komunikator diharuskan untuk mengungkapkan sebuah pernyataan yang mudah dipahami dan dimengerti oleh seluruh lapisan masyarakat (Danandjaja (2011:22)). Kata - kata tersebut bisa disampaikan sesuai dengan target audience yang diinginkan yakni secara verbal berupa tulisan seperti proposal atau press release, jumpa pers, dan announcer. Sedangkan non verbal melalui special event, berupa pameran atau kliping 
media (Frida Kusumastuti (2002:27)). Adapun klasifikasi tindak tutur yang diungkapkan oleh Searle (dalam Rusminto, 2010:22) yakni :

\begin{tabular}{|c|c|}
\hline Tindak tutur Lokusi & $\begin{array}{c}\text { Lokusi merupakan tindakan mengucapkan suatu } \\
\text { pernyataan yang lebih menitik beratkan pada isi } \\
\text { pernyataan atau tentang sesuatu }\end{array}$ \\
\hline Tindak tutur llokusi & $\begin{array}{c}\text { Ilokusi merupakan tindakan mempengaruhi } \\
\text { seseorang untuk melakukan tindakan tertentu } \\
\text { dalam hubungannya dengan mengatakan sesuatu }\end{array}$ \\
\hline Tindak tutur Perlokusi & $\begin{array}{c}\text { Perlokusi menitikberatkan pada efek yang timbul } \\
\text { ketika seseorang memahami definisi dan inti dari } \\
\text { pernyataan yang telah disampaikan }\end{array}$ \\
\hline
\end{tabular}

\section{Tindak Tutur Lokusi}

Humas telah melakukan kegiatan sosialisasi yang dilaksanakan melalui berbagai media, yakni media massa, baik cetak maupun elektronik, media sosial menggunakan media Instagram, dan media audio visual seperti KA TV, spanduk, roll banner, dan back drop. Humas juga telah melakukan kegiatan sosialisasi secara langsung di stasiun pada satu bulan pertama saat sosialisasi tersebut diluncurkan, dengan cara melakukan kegiatan cek kesehatan di klinik stasiun, melakukan jumpa pers di radio, serta saat sosialisasi angkutan lebaran. Empat dari lima orang penumpang, telah mengetahui secara pasti tentang informasi yang telah sosialisasikan oleh humas. Sumber media antar penumpangpun bermacam - macam, yakni dengan melalui Google, Spanduk di stasiun, bertanya dengan petugas stasiun serta dipanggil untuk melakukan cek kesehatan saat pihak perusahaan sedang melakukan sosialisasi di stasiun. Menurut Suprapto Humas PT. Kereta Api Indonesia (Persero) Daerah Operasi 4 Semarang, tujuan sosialisasi yang dilakukan oleh pihak perusahaan agar masyarakat memberikan perhatian terhadap prosedur atau peraturan yang telah disampaikan oleh perusahaan, mengingat sudah banyak kasus ibu melahirkan yang terjadi di PT. KAI (Persero), sehingga kasus tersebut bisa dijadikan contoh nyata bahwa peraturan dibuat juga memiliki manfaat, salah satunya adalah melindungi kesehatan ibu dan anaknya.

\section{Tindak Tutur Ilokusi}

Isi dari pernyataan tentang SOP Ibu Hamil adalah usia kandungan 14 - 28 minggu, diharuskan membawa surat keterangan dokter, harus didampingi suami atau salah seorang kerabat dekat untuk dimintai pertanggung jawaban. Usia kandungan dua dari lima penumpang tidak sesuai dengan ketentuan berlaku, Alicia beralasan bahwa melakukan perjalanan kereta api karena ingin melahirkan di kampung halaman, sedangkan Dina memiliki alasan karena tuntutan pekerjaan, sehingga mengharuskan dalam keadaan hamil besar melakukan tugas yang diberikan oleh perusahaannya 
kepadanya. Satu dari lima penumpang mengaku tidak membawa surat keterangan dokter. Riana beralasan bahwa membawa atau tidaknya surat keterangan dokter, petugas tidak pernah mengecek, ibu hamil diperlakukan sama seperti penumpang yang lain, tidak ada tindakan khusus dari perusahaan. Akan tetapi kelimanya mengaku sudah melakukan pengecekan ke dokter kandungan terlebih dahulu dengan alasan keselamatan perjalanan jauh. Masing - masing dokter kandunganpun memberikan izin untuk melakukan perjalanan jauh dengan catatan dengan menyarankan untuk menggunakan kereta api demi keamanan saat hamil.

\section{Tindak Tutur Perlokusi}

Efek atau tindakan yang dilakukan oleh penumpang juga beraneka ragam. Tindakan cenderung dominan patuh terhadap instruksi yang diberikan oleh perusahaan. Menurut Suprapto Humas PT. Kereta Api Indonesia (Persero) Daerah Operasi 4 Semarang, berkaca dari banyaknya kejadian ibu melahirkan di atas KA, tentunya menganggu kenyamanan penumpang yang lain dan mengganggu juga kelancaran perjalanan kereta api. Pihaknya melakukan antisipasi karena kejadian tersebut dianggap sangat berbahaya baik kesehatan ibu dan anaknya, karena fasilitas di kereta untuk melahirkan sangat darurat. Kontra yang terjadi adalah ibu hamil merasa pergerakannya di atasi, sehingga jika ingin bepergian tentunya memiliki kendala tersendiri. Pihak perusahaan melakukan tindakan persuasif dengan mempersilahkan ke klinik, ketika penumpang bersikukuh melakukan perjalanan tersebut selama ada yang mendampingi dan menandatangani surat pernyataan yang isinya menanggung resiko apapun kejadian selama perjalanan dan penumpang tersebut memaksa, jika tidak membawa pendamping tiketnya dikembalikan. Pembatasan tersebut juga dilakukan sebagai bentuk perhatian kita kepada ibu hamil. Bukan untuk kereta api, tapi untuk nyawa dan keselamatan penumpang tersebut.

\section{Simpulan}

Berdasarkan hasil penelitian tentang Analisis Tindak Tutur Humas PT. KAI (Persero) Daerah Operasi 4 Semarang dalam mensosialisasikan SOP No. 1/KS.102/II/MMH/9001/2017 tentang Rekomendasi Ibu Hamil dapat disimpulkan bahwa PT. Kereta Api Indonesia (Persero) Daerah Operasi 4 Semarang berusaha melakukan (lokusi) sosialisasi yang berisi pernyataan untuk mendapatkan hubungan kerjasama yang baik antara pihak perusahaan dan penumpang. Sosialisasi (ilokusi) dilakukan dengan berbagai media yakni media massa, media audio visual berupa KA TV, kegiatan Humas berupa himbauan dari announcer, talkshow dan jumpa pers saat angkutan lebaran serta iklan media massa berupa roll banner dan spanduk di lingkungan stasiun. Perusahaan memberikan pengertian kepada masyarakat khususnya ibu hamil untuk perduli dengan situasi dan kondisi saat melakukan perjalanan jauh. Setelah adanya 
kejadian ibu melahirkan, perusahaan melakukan evaluasi dengan cara memperketat filterisasi penumpang dengan kriteria ibu hamil, agar peristiwa melahirkan tidak terulang kembali.

\section{Saran}

Berdasarkan hasil penelitian tentang peran Humas PT. Kereta Api Indonesia (Persero) Daerah Operasi 4 Semarang dalam mensosialisasikan SOP No. 1/KS.102/II/MMH/9001/2017 tentang Rekomendasi Ibu Hamil, maka saran peneliti sebaiknya

1. Penelitian tentang media sosialisasi dapat dikaji lebih dalam lagi dari berbagai sudut pandang, yakni melalui bentuk tuturan lain, atau menganalisis pola kalimat dari berbagai media yang dijadikan alat sosialisasi.

2. Perusahaan melakukan evaluasi secara berkala terkait dengan respon masyarakat terhadap kebijakan yang telah berlaku di lingkunga stasiun, sehingga keberadaan pihak eksternal dapat dijadikan bahan tambahan evaluasi yang selanjutnya bisa membuat citra positif bagi perusahaan.

3. Saran peneliti selanjutnya, sosialisasi yang lebih informatif dapat dilakukan dengan menggunakan media sosial berupa Instagram dan menambahkan sistem di aplikasi KAI Access berupa informasi tambahan untuk ibu hamil sesuai dengan peraturan, sebagai pertanggung jawaban saat melakukan perjalanan jauh dengan kereta api.

4. Diperlukannya staff khusus atau media rekaman yang diputar secara berulang untuk menginformasikan peraturan di lingkungan stasiun maupun didalam kereta api, sehingga masyarakat yang belum terkontaminasi dengan peraturan tersebut, akan dengan mudah menyerap informasi yang disampaikan secara berulang.

\section{Daftar Pustaka}

Buku :

Adrian Sutedi. 2009. Metode Penelitian Hukum. Jakarta: Sinar Grafika

Afifudin dan Beni Ahmad Saebani. 2009. Metodologi Penelitian Kualitatif. Bandung: Pustaka Setia

Ardianto, Elvinaro. 2008. Public Relations Praktis. Bandung: Widya Padjajaran

. 2011. Metodologi Penelitian untuk Public Relations Kuantitatif dan Kualitatif. Bandung: Simbiosa Rekatama Media

Burhan, M Bugin. 2005. Metodologi Penelitian Kuantitatif: Komunikasi, Ekonomi dan Kebijakan

Publik serta IImu - IImu Sosial Lainnya, alih Burhan Wirasubrata. Jakarta: Serambi.

. 2014. Penelitian Kualitatif . Jakarta: Kencana Prenada Media.

Chaer, Abdul. 2010. Kesantunan Berbahasa. Jakarta: Rineka Cipta.

Damsar. 2011. Pengantar Sosiologi Pendidikan. Jakarta: Kencana.

Danandjaja. 2011. Peran Humas dalam Perusahaan. Yogyakarta: Graha Ilmu. 
Effendy, Onong Uchjana. 2002. Ilmu Komunikasi Teori dan Praktek. Bandung: PT. Remaja Rosdakarya.

Firsan Nova. 2011. Crisis Public Relations. Jakarta: Kencana.

Frida Kusumastuti. 2002. Dasar - Dasar Humas. Jakarta: Kencana.

Goffman, Erving. 2011. The Presentation of Self in Everyday Life. Jakarta: Erlangga

Hadari Nawawi. 2001. Metode Penelitian Sosial. Yogyakarta: Gajah Mada University Press

Insani, Istyadi. 2010. Standar Operasional Prosdur (SOP) sebagai Pedoman Pelaksanaan Administrasi Perkantoran dalam Rangka Peningkatan Pelayanan dan Kinerja Organisasi Pemerintah. Bandung

Ismail. 2013. Ironi dan Sarkasme Bahasa Politik Media. Yogyakarta: Pustaka Pelajar

Litthlejohn. 2017. Theories of Human Communication Elevent Edition. Long Grove, Illinois : Waveland Press, Inc

Moleong, Lexy J. (2007). Metodologi Penelitian Kualitatif. Bandung: PT. Remaja Rosdakarya

Morissan. 2009. Teori Komunikasi Massa : Media, Budaya dan Masyarakat. Bogor: Ghalia Indonesia

Mulyana, Deddy. 2004. Metodologi Penelitian Kualitatif. Bandung: PT Remaja Rosdakarya Nadar, F.X. 2009. Pragmatik dan Penelitian Pragmatik. Yogyakarta: Graha Ilmu.

Nana Syaodih Sukmadinata. 2009. Metode Penelitian Pendidikan. Bandung: Rosdakarya

Ruslan, Rosady. 2005. Manajemen Public Relation dan Media Komunikasi (Konsepsi dan Aplikasi). Jakarta: PT Raja Grafindo Persada.

2013. Metode Penelitian Public Relations dan Komunikasi. Jakarta: Raja Grafindo Persada.

Rusminto, Nurlaksana Eko. 2010. Memahami Bahasa Anak-Anak. Bandar Lampung: Universitas Lampung.

. 2012. Analisis Wacana Sebuah Kajian Teoritis dan Praktis. Bandar Lampung: Universitas Lampung.

Sailendra, Annie. 2015. Langkah-Langkah Praktis Membuat SOP. Trans Idea Publising: Jogjakarta.

Sugiyono, 2009. Metode Penelitian Kuantitatif, Kualitatif dan R\&D, Bandung : Alfabeta

\section{Sumber Data Perusahaan :}

(Sumber: https://kai.id/corporate/about kai)

Jurnal :

Ardelia Devy Pratami. 2014. Peran Humas Dalam Sosialisasi Kebijakan Pemerintah (Studi Peran Humas Dalam Sosialisasi Kebijakan Peraturan Pemerintah (Pp) No. 46/2013 Mengenai Pemberlakuan Pajak Ukm Di Kantor Wilayah Direktorat Jenderal Pajak Jawa Tengah Ii Kota Surakarta). Surakarta : Universitas Negeri Surakarta 
Sumber : https://digilib.uns.ac.id/

Arum Puji Astuti. 2014. Analisis Tindak Tutur Pada Spanduk Di Wilayah Sukoharjo : Tinjauan Pragmatik. Surakarta : Universitas Muhammadiyah Surakarta.

Sumber : https://eprints.ums.ac.id

Fikka Pratiwi. 2017. Strategi Komunikasi Humas PT. KAIDAOP 3 Cirebon Dalam Mensosialisasikan Keselamatan Perjalanan Kereta Api Kepada Pelajar. Semarang : Universitas Diponegoro Sumber : $\underline{\text { http://eprints.undip.ac.id/61143 }}$

Putu Ayu Intan Cahaya Dewi. 2017. Strategi Komunikasi Humas PT. PLN (Persero) Distribusi Jawa Timur dalam Menyosialisasikan Program Pencabutan Subsidi Listrik Daya 900VA. Jawa Timur : Universitas Kristen Petra.

Sumber : http://publication.petra.ac.id/index.php/ilmu-komunikasi/

Sri Indah Purwati. 2014. Aktivitas Humas Pemerintah Kota Pekanbaru Dalam Mensosialisasikan Program Gerakan Sekolah Bersepeda. Kepulauan Riau : UIN Sultan Syarif Kasim Riau.

Sumber : http://repository.uin-suska.ac.id/4871/

Titis Hidayati. 2014. Peran Humas dalam Implementasi UU No 14 Tahun 2008 Tentang Keterbukaan Informasi Publik di Badan Publik (Studi Kasus pada Badan Pemeriksa Keuangan RI). Yogyakarta : Universitas Gajah Mada.

Sumber : http://etd.repository.ugm.ac.id/

\title{
Sumber berita :
}

(https://news.detik.com/berita/3430688/pt-kai-bikin-aturan-untuk-ibu-hamil-naik-ka-jarakjauh, diakses tanggal 04/12 09.29 WIB).

(https://lifestyle.kompas.com/read/2018/08/09/210000220/ibu-hamil-perhatikan-panduanini-jika-ingin-naik-kereta-api, diakses tanggal 04/12 09.42 WIB).

(https://www.cnnindonesia.com/nasional/20180618081238-20-306950/seorang-pemudikmelahirkan-di-kereta-api, diakses tanggal 04/12, 09.50 WIB).

(https://www.jawapos.com/ipg-today/17/06/2018/seorang-ibu-melahirkan-di-ka-dalamperjalanan-mudik, diakses tanggal 04/12, 09.59 WIB).

(http://www.perkeretaapian.net/2018/06/dalam-perjalanan-mudik-seorang-ibu.html diakses tanggal 04/12, 10.03 WIB).

(http://jakarta.tribunnews.com/2018/06/18/mudik-ke-surabaya-seorang-ibu-melahirkan-dikereta-api-begini-kondisi-sang-bayi, diakses tanggal 04/12, 10.13 WIB).

\author{
Media sosial : \\ Instagram PT. KAI (Persero) \\ @keretaappikita \\ @kai121_
}

